\title{
Evde Ders Okulda Ödev Modelinin Akademik Başarı, Kalıcılık ve Uzun Vadede Kalıcılığa Etkisi*
}

\section{Mehmet Fatih KAYAN** ve Abdullah ADIGÜZEL***}

Öz: Bu araştırmanın amacı, Evde Ders Okulda Ödev (EDOÖ) modelinin öğretmen adaylarının akademik başarılarına, öğrenmelerinin kısa ve uzun vadede kalıcılığına etkisini ortaya koymak ve EDOÖ modeline ilişkin görüşlerini belirlemektir. Çalışmada, karma yöntem deseni kullanılmıştır. Araştırma bir devlet üniversitesinin Eğitim Fakültesi Fen Bilgisi Öğretmenliği bölümünde öğrenim görmekte olan 38 öğretmen adayı ile "Eğitim Psikolojisi” dersinde yürütülmüştür. Öğretmen adayları iki gruba ayrılmış ve gruplar seçkisiz olarak deney ve kontrol grubu olarak belirlenmiştir. Deney grubunda EDOÖ modeli uygulanmış, kontrol grubunda ise geleneksel sunuş yöntemi kullanılmıştır. Araştırmada nicel ve nitel veri toplama araçları kullanılmıştır. Nicel veri toplama aracı olarak Akademik Başarı Testi kullanılmıştır. Nitel veri toplama aracı olarak ise yarı-yapılandırılmış görüşme formu kullanılmıştır. Nicel verilerin analizi için betimsel istatistikler, bağımsız gruplar için t-testi, bağımlı gruplar için t-testi, tekrarlı ölçümlerde ANOVA ve ANCOVA testleri kullanılmıştır. Nitel verilerin analizinde ise betimsel ve içerik analizi tekniklerinden yararlanılmıştır. Araştırmadan elde edilen bulgulara göre deney grubu öğretmen adaylarının akademik başarılarının kontrol grubu adaylarına göre anlamlı düzeyde daha yüksek olduğu sonucuna ulaşılmıştır. Deney ve kontrol grubu öğretmen adaylarının, kalıcılık puanları arasında anlamlı düzeyde bir farklılığın olmadığı görülmüştür. Uygulama sürecinin sona ermesinden 6 ay sonra öğrenmelerin uzun vadede kalıcılığını ölçmeye yönelik olarak yapılan ikinci kalıcılık testi sonuçlarına göre de deney ve kontrol grupları arasında anlamlı bir farklılık bulunmamıştır. Deney grubu öğret ${ }^{1}$ men adaylarının genel olarak

\footnotetext{
* Bu çalışma birinci yazarın "Evde Ders Okulda Ödev modelinin akademik başarı, kalıcılık ve sınıf iklimi üzerindeki etkisi” isimli doktora tez çalışmasından türetilmiştir.

$\mathrm{Bu}$ araştırmanın verileri 2017-2018 eğitim-öğretim yılında elde edildiğinden yayın etik kurulu izni alınmamıştır.

${ }^{* *}$ Dr. Öğr. Üyesi. Harran Üniversitesi İlahiyat Fakültesi Felsefe ve Din Bilimleri Bölümü, e-mail: kayanfatih@yahoo.com, ORCID ID: 0000-0002-4702-4080.

*** Prof. Dr. Düzce Üniversitesi Eğitim Fakültesi Eğitim Bilimleri Bölümü, e-mail: aadgzel@gmail.com, ORCID ID: 0000-0001-7184-3644.
}

\begin{tabular}{lll}
\hline Gönderim:30.08.2021 Kabul: 02.10.2021 & Yayın:15.12.2021
\end{tabular}


EDOÖ modeline yönelik olumlu bir tutuma sahip oldukları ve modeli işlevsel olarak değerlendirdikleri görülmüştür.

Anahtar Sözcükler: Evde Ders Okulda Ödev Modeli, Akademik başarı, kalıcılık, uzun vadede kalıc1lik

\section{The Effect of Flipped Learning Model on Academic Achievement, Retention and Long- Term Retention}

Abstract: The aim of this study is to investigate the effect of flipped learning model on academic achievement, knowledge retention and long-term knowledge retention of prospective teachers and to determine their opinions concerning the model. In this study, mixed method design was used. The study was conducted in a "Educational Psychology" course with 38 prospective teachers who study Science Education in Faculty of Education in a public university. Prospective teachers were divided into two groups and the groups were randomly assigned as experimental and control groups. Flipped learning model was applied in the experimental group and for the control group traditional method was used. Quantitative and qualitative data collection tools were used in the study. Academic achievement test was used as a quantitative data collection tool and for the qualitative data collection, semi-structured interview form was used. Descriptive statistics, t-test for independent groups, t-test for dependent groups, ANOVA and ANCOVA tests were used for the analysis of quantitative data. For the analysis of qualitative data, descriptive and content analysis techniques were used. It was found that the academic achievement of the experimental group was significantly higher than the control group. Besides, it was found that there was no significant difference between knowledge retention of the prospective teachers in experimental and control group. Six months after the application process there was no significant difference between experimental and control groups in terms of the second knowledge retention test results to measure the long-term knowledge retention. It was concluded that prospective teachers have a positive attitude towards the flipped learning model and considered the model as functional.

Keywords: Flipped Learning Model, academic achievement, knowledge retention, long-term knowledge retention

\section{Giriş}

Günümüzde konu merkezli geleneksel öğretim modelleri, öğrenenleri öğrenme-öğretme süreçlerinde pasifleştirmesi ve öğrenilen bilgilerin kalıcılığını sağlayamaması gibi nedenlerden 
dolayı sıkça eleştirilmekte ve günden güne değer kaybetmektedirler. Öğrencilerin öğrenme hızlarını göz ardı eden, zaman ve mekân bağlamında öğrenenlere yeterli düzeyde bir esneklik sunmayan geleneksel öğretim modelleri ihtiyaca cevap vermekten uzak bir görüntü sergilemektedirler (Akınoğlu, 2005). Bu doğrultuda gelişime öncülük etme amacıyla öğrenmeöğretme süreçlerinde işe koşulmak üzere yeni yaklaşımlar benimsenmeye ve uygulanmaya başlanmıştır (Adıgüzel, 2016). Eğitim paradigmalarında meydana gelen tüm bu değişimlerin ortak amac1 öğrencilerin öğrenme süreçlerinde aktif bir rol üstlenmesi ve bilginin öğrenen tarafından anlamlandırılması olarak düşünülebilir.

$\mathrm{Bu}$ bağlamda öğretmen ve öğrenci rollerinde meydana gelen değişimler sonucunda ortaya çıkan modellerden biri de Evde Ders Okulda Ödev (Flipped Learning) modelidir (Kardaş ve Yeşilyaprak, 2015). Evde Ders Okulda Ödev (EDOÖ) modeline dair ilk görüşler Baker (2000) ve Lage, Platt ve Treglia (2000) tarafından ortaya atılmıştır. Baker ve Lage vd., gerçekleştirmiş oldukları çalışmalarda sınıf içi ve sınıf dışı etkinliklerin tersine çevrilmesinin öğrenme sürecine katkı sağlayabilecek bir uygulama olabileceğini öne sürmüşlerdir. Modelin dünyaya açılmasına öncülük eden Bergmann ve Sams (2012) ise EDOÖ modelini, sınıf içi ve sınıf dışı uygulamaların tamamıyla ters yüz edildiği, öğrencilerin ders öncesinde ilgili konuyu öğrenerek derse hazır bir şekilde katıldıkları yeni bir yöntem olarak tanımlamaktadırlar. EDOÖ modelinin ders sürecinde ise öğrencilerin sınıf ortamının getirilerinden faydalanarak ders öncesinde edindikleri bilgileri özümsemeleri amaçlanmaktadır.

EDOÖ modeli ile ilgili olarak yapılan en genel tanım, geleneksel öğretim modelinde sınıf içerisinde işe koşulan etkinliklerin (bilginin transferi) öğrenciler tarafından ders dışında yapılması, sınıf dışı etkinliklerin (bilginin öğrenci tarafından özümsenmesi) ise öğretmen gözetiminde sınıf ortamında gerçekleşmesi şeklindedir (Lage vd., 2000). EDOÖ modelinin en sık rastlanılan uygulama biçiminde öğrenciler, öğretmen tarafindan kendilerine sunulan videolar, sunular, dokümanlar gibi materyallerle dersin kuramsal kısmını önceden öğrenir ve buna ek olarak bireysel çalışmalar ve araştırmalar yaparak derse hazır olarak gelirler. Ders sürecinde ise öğrenciler, iletişim ve etkileşim olanaklarına sahip oldukları sınıf ortamında önceden öğrendikleri bilgileri arkadaşları ile paylaşır ve tartışma vb. yöntemlerle bilgilerini pekiştirirler. Bunların yanı sıra öğrenciler, öğretmen tarafından hazırlanmış olan etkinlikler ile ders öncesinde edinmiş oldukları öğrenmeleri uygulama imkânına sahip olurlar (Seaman ve Gaines, 2013). Böylelikle eğitim sürecinin bilginin transferine nazaran daha zor ve önemli boyutu olan bilginin özümsenmesi aşaması öğretmen rehberliğinde sınıf ortamında gerçekleşir ve bilgiler öğrenenler tarafindan anlamlandırılır (Bergmann ve Sams, 2008). 
EDOÖ modeli öğretmen merkezli bir öğrenme ortamından öğrenci odaklı bir ortama geçiş olarak nitelendirilmektedir. Bu bağlamda EDOÖ modelinin öğrenciler açısından birçok getirileri bulunmaktadır. Öncelikle model, öğrencilere aktif bir öğrenme ortamı sunmaktadır (Herreid ve Schiller, 2013). Bunun yanı sıra öğrenciler, sahip oldukları becerileri dışarıya yansıtabilme ve uygulayabilme olanaklarına sahip olmaktadırlar. Tüm bunların yanında EDOÖ modeli öğrencilere anlamlı öğrenme firsatı sunmaktadır. Birçok eğitim bilimcinin ortak görüşüne göre anlamlı öğrenmenin sağlanabilmesi için ders içi süreçte tartışma, uygulama, analiz etme, problem çözme gibi becerilerin öğrenciler tarafindan yoğun olarak tecrübe edilmesi gerekmektedir. Ders içi sürecin öğrenen merkezli etkinlikler aracılığıyla yürütüldüğü EDOÖ modelinde ise bahsi geçen uygulamalara geniş bir yer verilmektedir (Leicht, Zappe, Messner ve Litzinger, 2012).

Diğer birçok çağdaş öğrenme modeline nazaran yükseköğretim seviyesinde de kullanım alanına sahip olan EDOÖ modeli başta $A B D$ ve Avustralya olmak üzere çok sayıda ülkede üniversite öğrencilerine yönelik olarak uygulanmaktadır. Nitekim temel amaçlarından biri öğrencilerin bireysel hızlarında öğrenmelerine firsat vermek olan EDOÖ modeli bu bağlamda değerlendirildiğinde yükseköğretim düzeyi için oldukça cazip bir görüntü sergilemektedir. Özellikle yoğun bir içeriğe sahip olan derslerde, öğrencilere kendi öğrenme stillerine ve bireysel hızlarına göre süreci yürütme olanağı tanıması bakımından yakın gelecekte öğretim elemanları tarafindan yoğun olarak tercih edilmesi beklenmektedir.

Sınıf içi ve sınıf dışı etkinlikleri tersine çevirme fikrini ilk olarak ortaya koyan Baker (2000) ve Lage vd. (2000) bu uygulamaya ilişkin önerilerini üniversite öğrencilerine yönelik olarak ele almışlardır. Lage vd. (2000) göre üniversitelerde sınıf içi ve sınıf dışı etkinliklerin tersine çevrilmesi özellikle yoğun bir müfredata sahip olan sosyal alanlarda öğretim elemanlarına büyük kolaylıklar sağlayacak ve dersin daha verimli bir şekilde işlenmesine yol açacaktır. Bunun yanında EDOÖ modeli kalabalık sınıflara eğitim vermekte olan öğretim elemanlarına, öğrenme-öğretme süreçlerinin daha nitelikli olarak yürütülmesi ve öğrencilerin derslere aktif katılımının sağlanması noktasında önemli kolaylıklar sağlamaktadır (Newman vd., 2016).

\section{Araştırmanın Amacı ve Önemi}

$\mathrm{Bu}$ araştırmanın amacı, EDOÖ modelinin öğretmen adaylarının akademik başarılarına, öğrenmelerinin kısa ve uzun vadede kalıcılığına etkisini ortaya koymak ve EDOÖ modeline ilişkin görüşlerini belirlemektir. Bu genel amaç doğrultusunda aşağıdaki sorulara cevap aranmaktadır. 
1. Deney grubundaki öğretmen adaylarının ön test, son test ve kalıcılık testi akademik başarı puanları arasında anlamlı bir fark var mıdır?

2. Kontrol grubundaki öğretmen adaylarının ön test, son test ve kalıcılık testi akademik başarı puanları arasında anlamlı bir fark var mıdır?

3. Deney ve kontrol gruplarındaki öğretmen adaylarının akademik başarı son test puanları arasında anlamlı bir fark var mıdır?

4. Deney ve kontrol gruplarındaki öğretmen adaylarının akademik başarı kalıcılık testi puanları arasında anlamlı bir fark var midir?

5. Deney grubundaki öğretmen adaylarının son test, 1. kalıcılık ve 2. kalıcılık testi akademik başarı puanları arasında anlamlı bir fark var mıdır?

6. Kontrol grubundaki öğretmen adaylarının son test, 1. kalıcılık ve 2. kalıcılık testi akademik başarı puanları arasında anlamlı bir fark var mıdır?

7. Deney ve kontrol gruplarındaki öğretmen adaylarının akademik başarı 2. kalıcılık testi puanları arasında anlamlı bir fark var mıdır?

8. Deney grubu öğretmen adaylarının EDOÖ modeline ilişkin görüşleri nelerdir?

Yapılandırmacı öğrenme yaklaşımının bir uzantısı olarak ortaya çıkan öğrenen merkezli çağdaş öğrenme modelleri daha çok ilk ve orta düzey basamaklara hitap etmektedir. Bu doğrultuda bu çalışma, öğrenen merkezli bir model olan EDOÖ modelinin eğitim fakültesinde öğrenim görmekte olan öğretmen adaylarının akademik başarıları ve kalıcılıklarına etkisini belirlemesi açısından önemlidir.

\section{Yöntem}

\section{Araştırmanın Deseni}

$\mathrm{Bu}$ çalışma, nitel ve nicel veri toplama yöntemlerinin bir arada kullanıldığı karma yöntem ile yürütülmüştür. Balcı (2011) karma yöntem araştırmayı, araştırmacının nitel araştırmayı araştırmanın bir aşamasında, nicel paradigmayı ise diğer aşamasında kullanması olarak ifade etmektedir. Bu araştırma yaklaşımının temel varsayımına göre, nitel ve nicel yaklaşımların birlikte kullanılması araştırma problemi ile ilgili daha kapsamlı bir anlayışın oluşmasını sağlar ve araştırmacıların, çalışmalarına ilişkin alternatif bir bakış açısı kazanmalarına yardımcı olur (Creswell, 2013).

Bu araştırma, açıklayıcı sıralı karma yöntem deseni ile yürütülmüştür. Açıklayıcı sıralı desende araştırma süreci iki aşamadan meydana gelir. Öncelikli olarak nicel verilerin toplandığı bu desende, verilerden elde edilen sonuçlara bağlı olarak nitel veriler toplanır. Sıralı açıklayıcı desenlerde ilk etapta genel olarak ölçek ve/veya anketler aracılığıyla nicel veriler toplanır ve 
analiz edilir. Sonraki aşamada ise derinlemesine bilgi sahibi olmak amacıyla görüşmeler yapılır. Açıklayıcı sıralı desenlerde nicel ve nitel veriler ayrı ayrı analiz edilir, tartışma bölümünde ise bu veriler birleştirilerek yorumlanır (Creswell, 2013; Fraenkel, Wallen, \& Hyun, 2012).

Araştırmanın nicel boyutunda gerçek deneysel desen kullanılmıştır. Büyüköztürk, KılıçÇakmak, Akgün, Karadeniz ve Demirel (2012) gerçek deneysel desenleri, katılımcıların bağımsız değişkenin düzeylerine, gruplara seçkisiz olarak yerleştirildiği çalışmalar olarak tanımlamaktadır. Ön test-son test kontrol gruplu seçkisiz desen olarak da bilinen bu desen eğitim ve psikolojide çok sık kullanılan deneysel desenlerden biridir. Burada ilk olarak daha önce belirlenen denek havuzundan seçkisiz atama ile iki grup oluşturulur. Gruplardan biri deney, diğeri kontrol grubu olarak seçkisiz bir şekilde belirlenir. Daha sonra iki grupta yer alan deneklerin, uygulama öncesinde bağımlı değişkenle ilgili ölçümleri alınır. Uygulama sürecinde ise etkisi test edilen deneysel işlem, deney grubuna verilirken kontrol grubuna verilmez. Son olarak gruplardaki deneklerin bağımlı değişkene ait ölçümleri aynı araç kullanılarak tekrar edilir.

Araştırma için Eğitim Fakültesi 1. sınıfta öğrenim görmekte olan bir grup öğretmen adayı seçkisiz atama yoluyla iki gruba ayrılmış ve gruplar seçkisiz olarak deney ve kontrol grubu olarak belirlenmiştir. Araştırma sürecinde Eğitim Psikolojisi dersi, deney grubunda EDOÖ modeli ile kontrol grubunda ise geleneksel öğretim modeli ile yürütülmüştür. Araştırmanın bağımsız değişkenini farklı öğretim yöntemi, bağımlı değişkenini ise öğretmen adaylarının akademik başarıları oluşturmuştur.

Tablo 1. Çalışmada Uygulanacak Deneysel Desenin Görünümü

\begin{tabular}{ccccccc}
\hline & Grup & Ön test & $\begin{array}{c}\text { Deneysel } \\
\text { işlem }\end{array}$ & Son test & $\begin{array}{c}\text { 1.Kalıcılık } \\
\text { Testi }\end{array}$ & $\begin{array}{c}\text { 2.Kalıcılık } \\
\text { Testi }\end{array}$ \\
$\mathrm{R}$ & $\mathrm{D}$ & $\mathrm{O} 1$ & $\mathrm{X}$ & $\mathrm{O} 3$ & $\mathrm{O} 5$ & $\mathrm{O}$ \\
$\mathrm{R}$ & $\mathrm{K}$ & $\mathrm{O} 2$ & İşlem yok & $\mathrm{O} 4$ & $\mathrm{O} 6$ & $\mathrm{O}$ \\
\hline
\end{tabular}

Tablo 1'de görüldüğü üzere çalışmada biri deney diğeri kontrol olmak üzere iki farklı grup bulunmaktadır. Deney grubu EDOÖ modeli ile dersin yürütüldüğü gruptur. Kontrol grubunda ise ders geleneksel öğretim modeli ile işlenmiştir. Gruplara ön test olarak öğretmen adaylarının önbilgi düzeylerini belirlemeye yönelik olarak başarı testi uygulanmıştır. Uygulamanın sonunda aynı test aynı gruplara yeniden uygulanmıştır. Sürecin sona ermesinden dört hafta sonra başarı testi tekrardan uygulanarak öğrenmelerin kalıcılığı ölçülmüştür. Akademik başarı testi kalıcılık testinden 6 ay sonra son bir kez uygulanarak uzun vadede kalıcılığın ölçülmesi amaçlanmıştır. 


\section{Çalışma Grubu}

Araştırmanın çalışma grubunu 2017-2018 öğretim yılında bir devlet üniversitesinin Eğitim Fakültesi Fen Bilgisi Öğretmenliği programında öğrenim görmekte olan 1. sınıf öğrencileri oluşturmaktadır. Çalışma grubunu oluşturan bireyler, seçkisiz örnekleme yöntemlerinden basit seçkisiz örnekleme ile iki gruba ayrılmış ve gruplar seçkisiz olarak deney ve kontrol grubu olarak belirlenmiştir. Basit seçkisiz örnekleme yönteminde tüm birimler örnekleme seçilmek için eşit ve bağımsız bir şansa sahiptirler (Büyüköztürk vd., 2012). Bu doğrultuda çalışma grubunda yer alan 38 öğretmen adayının tamamına, toplam 35 sorudan oluşan akademik başarı testi ön test olarak uygulanmıştır. Akademik başarı testinden elde edilen sonuçlara göre aynı ve benzer puanı alan öğretmen adayları seçkisiz olarak iki farklı grubu atanmıştır. Çalışma grubunda yer alan öğretmen adaylarının tamamının birer gruba ataması yapıldıktan sonra, grupların hangisinin deney hangisinin kontrol grubu olacağına kura ile karar verildi. Böylelikle deney ve kontrol gruplarının uygulama sürecinden önce akademik başarı bağlamında eşit düzeyde olmaları sağlandı.

Tablo 2. Deney ve Kontrol Grubundaki Öğretmen Adaylarının Akademik Başarı Ön Test Puanlarına İlişkin Bağımsız Gruplar t-Testi Sonuçları

\begin{tabular}{|c|c|c|c|c|c|c|}
\hline Grup & $\mathbf{N}$ & $\bar{x}$ & Ss & Sd & $t$ & p \\
\hline Deney & 19 & 12.21 & 2.42 & \multirow{2}{*}{36} & \multirow{2}{*}{-.065} & \multirow{2}{*}{.95} \\
\hline Kontrol & 19 & 12.26 & 2.60 & & & \\
\hline
\end{tabular}

Tablo 2'de görüldüğü üzere, deney ve kontrol grubundaki öğretmen adaylarının akademik başarı ön test puanları arasında istatistiksel olarak anlamlı bir farklılık bulunmamaktadır $(\mathrm{t}(36)=-.065 ; \mathrm{p}>.05)$. Dolayısıyla deney ve kontrol gruplarının sürecin başında akademik başarı açısından denk oldukları söylenebilir.

Fen bilgisi öğretmenliği programı 1. sınıfta öğrenim görmekte olan 38 öğrencinin tümü araştırmaya dâhil edilmiştir. Adayların 19'u deney, 19'u ise kontrol grubuna atanmıştır. Deney grubunda yer alan öğretmen adaylarından 16'sı kadın 3'ü erkektir. Kontrol grubunda yer alan öğretmen adaylarının ise 15 'i kadın 4'ü erkektir.

\section{Veri Toplama Araçları}

Karma yöntem ile yürütülen bu çalışmada nicel ve nitel veri toplama yöntemleri kullanılmıştır. Nicel veri toplama aracı olarak akademik başarı testi, (ön test, son test, kalıcılık 
YYÜ Eğitim Fakültesi Dergisi (YYU Journal of Education Faculty), 2021;18(2)300-331,http://efdergi.yyu.edu.tr,

testi ve 2. kalıcılık testi) nitel veri toplama aracı olarak ise yarı-yapılandırılmış görüşme formu kullanılmıştır. Çalışmanın verileri 2017-2018 öğretim yılının bahar döneminde toplanmıştır.

\section{Akademik Başarı Testi}

Akademik başarı testi, eğitim psikolojisi dersinde yer alan kazanımlar dikkate alınarak geliştirilmiştir. Testte, eğitim psikolojisi dersinde yer alan kazanımlardan yola çıkılarak Bloom taksonomisine göre bilgi, kavrama, uygulama ve analiz düzeyinde sorulara yer verilmiştir. Akademik başarı testinin hazırlanması sürecinde öncelikle kaynak kitaplardan yararlanılarak her kazanıma yönelik ortalama 1-2 soru yer alacak şekilde toplam 40 sorudan oluşan bir test geliştirilmiştir. Sorular, 5 seçenekli çoktan seçmeli test türünde hazırlanmıştır. Test hazırlanırken çoktan seçmeli soru hazırlama ilkeleri dikkate alınmıştır. Testin geçerlik ve güvenirliği için yapılan işlemler aşağıda açıklanmıştır.

\section{Akademik Başarı Testinin Geçerlik ve Güvenirliği}

Geçerlilik, hazırlanan testin ölçülmesi istenen özelliğe yönelik bilgilerin toplanmasına hizmet etme derecesidir (Kaptan, 1998). Bu araştırmada akademik başarı testinin geçerliğinin değerlendirilmesinde uzman görüşlerine başvurulmuştur. Test üç program geliştirme uzmanı, iki alan uzmanı ve iki Türkçe eğitimi anabilim dalı öğretim üyesi tarafından incelenmiştir. Yapılan incelemeler sonucunda soruların genel olarak eğitim fakültesi 1. sınıf öğrencilerinin seviyelerine uygun düzeyde olduğu ve kapsam geçerliğine sahip olduğu kanaatine varılmıştır. Daha sonra uzmanlardan gelen dönütler doğrultusunda sorular üzerinde gerekli düzenlemeler yapılmış ve 40 sorudan oluşan akademik başarı testi pilot uygulamaya hazır hale getirilmiştir.

Testte zayıf olarak belirlenen 5 sorunun çıkarılmasından sonra geriye kalan 35 sorunun madde ayırt edicilik derecelerine göre dağılımı şu şekilde gerçekleşmiştir; 16 madde 0.40'tan büyük (çok iyi madde), 11 madde 0.30-0.40 arası (iyi madde), 8 madde 0.20-0.29 arası (orta derecede madde).

Gerçekleştirilen düzeltme ve madde çıkarma işlemlerinin neticesinde 35 maddelik başarı testi uygulamaya hazır hale getirilmiştir. Testte kalan maddelerin madde güvenirliklerinin 0.09-0.30 arasında, madde güçlüklerinin 0.22-0.81 arasında olduğu ve testin ortalama güçlügünün 0.50 olduğu belirlenmiştir. Ayrıca, testte kullanılacak soruların madde varyansları 0.15-0.25 arasında; madde ayırt edicilikleri ise 0.21-0.60 arasında değişmektedir.

\section{Yarı Yapılandırılmış Görüşme Formu}

Araştırmacı sürecin sonunda deney grubunda yer alan 19 öğretmen adayının tamamı ile yarı yapılandırılmış görüşmeler gerçekleştirmiştir. Bu doğrultuda uygulama sürecine yönelik 
daha derinlemesine bilgi sahibi olma ve akademik başarı testi aracılığıyla elde edilen verilerin güvenirliğini tespit etme amacı taşıyan üç sorudan oluşan yarı-yapılandırılmış bir görüşme formu hazırlanmıştır. Araştırmacı tarafından geliştirilmiş olan yarı yapılandırılmış görüşme formunda açık uçlu ve kolay anlaşılır sorulara yer verilmiştir.

Görüşme formunda yer alan soruların anlaşılırlığını ve araştırmanın amacına uygunluğunu belirlemek amacıyla üçü Eğitim Programları ve Öğretim, ikisi de Eğitimde Ölçme ve Değerlendirme olmak üzere beş alan uzmanından görüş alınmıştır. Taslak görüşme formunda uzmanlar arasında büyük ölçüde görüş birliği olan sorular aynen alınmış, düzeltilmesi gereken sorular uzmanların dönütleri ve önerileri doğrultusunda düzenlenmiştir.

\section{Verilerin Analizi}

Karma yöntemin kullanıldığı bu araştırmada nicel ve nitel veri analizi tekniklerinden yararlanılmıştır. Nicel verilerin analizi için SPSS paket programı kullanılarak betimsel istatistikler, bağımsız gruplar için t-testi, bağımlı gruplar için t-testi, tekrarlı ölçümlerde ANOVA ve ANCOVA testleri kullanılmıştır. Nitel verilerin analizinde ise betimsel ve içerik analizi teknikleri işe koşulmuştur.

\section{Bulgular}

\section{Nicel Verilere İlişkin Bulgular}

\section{Birinci Alt Probleme İlişkin Bulgular}

Araştırmanın birinci alt problemi "Deney grubundaki öğretmen adaylarının ön test, son test ve kalıcılık testi akademik başarı puanları arasında anlamlı bir fark var mıdır?” şeklindedir. Bu probleme yanıt verebilmek için geliştirilen akademik başarı testi deney grubuna ön test, son test ve kalıcılık testi olarak uygulanmış ve uygulamalardan elde edilen veriler analiz edilmiştir. Tablo 3. Deney Grubundaki Öğretmen Adaylarının Ön Test, Son Test ve Kalıcılık Testi Akademik Başarı Puanlarına İlişkin Betimsel İstatistikler

\begin{tabular}{llll}
\hline Test & $\mathbf{N}$ & $\overline{\boldsymbol{x}}$ & Ss \\
\hline Ön Test & 19 & 12.21 & 2.42 \\
\hline Son Test & 19 & 22.47 & 4.31 \\
\hline Kalıc1lk Testi & 19 & 20.95 & 3.91 \\
\hline
\end{tabular}

Tablo 3 incelendiğinde, deney grubundaki öğretmen adaylarının ön testten aldıkları puanların aritmetik ortalamasının $\overline{\mathrm{x}}=12.21$, son testten aldıkları puanların aritmetik ortalamasının $\overline{\mathrm{x}}=22.47$ ve kalıcılık testinden elde ettikleri puanların aritmetik ortalamasının $\overline{\mathrm{X}}=20.95$ olduğu görülmektedir. Bu bulgu, deney grubunda bulunan öğretmen adaylarının son 
YYÜ Eğitim Fakültesi Dergisi (YYU Journal of Education Faculty), 2021;18(2)300-331,http://efdergi.yyu.edu.tr,

test puanlarının ön test puanlarına göre arttığını, kalıcılık testi puanlarının ise son test puanlarına göre biraz düştügünü göstermektedir.

Deney grubunda bulunan öğretmen adaylarının ön test, son test ve kalıcılık testi puanları arasında anlamlı bir farklılık olup olmadığını belirlemek için yapılan Tekrarlı Ölçümlerde ANOVA Testi sonuçları Tablo 4'de verilmiştir.

Tablo 4. Deney Grubunun Ön Test, Son Test ve Kalıcılık Testi Puanlarına İlişkin Tekrarlı Ölçümlerde ANOVA Sonuçları

\begin{tabular}{|c|c|c|c|c|c|c|}
\hline $\begin{array}{l}\text { Varyansın } \\
\text { Kaynağı }\end{array}$ & KT & SD & KO & $\mathbf{F}$ & $\mathbf{p}$ & $\begin{array}{c}\text { Anlamlı } \\
\text { Fark }\end{array}$ \\
\hline Deneklerarası & 504.807 & 18 & 28.045 & \multirow{4}{*}{99.87} & \multirow{4}{*}{.00} & \multirow{4}{*}{$\begin{array}{c}1-2,1-3,2- \\
3\end{array}$} \\
\hline Ölçüm & 1165.298 & 2 & 582.649 & & & \\
\hline Hata & 210.035 & 36 & 5.834 & & & \\
\hline Toplam & 1880.140 & 56 & & & & \\
\hline
\end{tabular}

Tablo 4'de görüldüğü üzere, deney grubunda bulunan öğretmen adaylarının ön test, son test ve kalıcılık testi puanları arasında istatistiksel olarak anlamlı bir farklılık vardır $(\mathrm{p}<.05) . \mathrm{Bu}$ farkın hangi ölçümler arasından kaynaklandığını belirlemek amacıyla başvurulan Bonferroni testi sonucuna göre, ön test-son test puanları arasında son test lehine, ön test-kalıcılık testi puanları arasında kalıcılık testi lehine ve son test-kalıcılık testi puanları arasında son test lehine anlamlı bir fark vardır. Buna göre, EDOÖ modelinin akademik başarıyı arttırmasına karşın, kalıcılık sağlayamadı̆̆ı görülmektedir.

\section{İkinci Alt Probleme İlişkin Bulgular}

Araştırmanın ikinci alt problemi "Kontrol grubundaki öğretmen adaylarının ön test, son test ve kalıcılık testi akademik başarı puanları arasında anlamlı bir fark var mıdır?” şeklindedir. Bu probleme yanıt verebilmek için geliştirilen akademik başarı testi kontrol grubuna ön test, son test ve kalıcılık testi olarak uygulanmış ve uygulamalardan elde edilen veriler analiz edilmiştir.

Tablo 5. Kontrol Grubundaki Öğretmen Adaylarının Ön Test, Son Test ve Kalıcılık Testi Akademik Başarı Puanlarına İlişkin Betimsel İstatistikler

\begin{tabular}{lccc}
\hline Test & $\mathbf{N}$ & $\overline{\boldsymbol{x}}$ & Ss \\
\hline Ön Test & 19 & 12.26 & 2.60 \\
\hline Son Test & 19 & 18.63 & 4.36 \\
\hline Kalıc1lık Testi & 19 & 18.90 & 4.36 \\
\hline
\end{tabular}


Tablo 5'e bakıldığında, kontrol grubunda bulunan öğretmen adaylarının ön testten aldıkları puanların aritmetik ortalamasının $\bar{x}=12.26$, son testten aldıkları puanların aritmetik ortalamasının $\overline{\mathrm{x}}=18.63$ ve kalıcılık testinden elde ettikleri puanların aritmetik ortalamasının $\overline{\mathrm{X}}=18.90$ olduğu görülmektedir. Bu bulgu, kontrol grubunda bulunan öğretmen adaylarının son test puanlarının ön test puanlarına göre arttığını, kalıcılık testi puanlarının son test puanları ile hemen hemen aynı olduğunu göstermektedir.

Kontrol grubunda yer alan öğretmen adaylarının ön test, son test ve kalıcılık testi puanları arasında anlamlı bir farklılık olup olmadığını belirlemek için yapılan Tekrarlı Ölçümlerde ANOVA Testi sonuçları Tablo 6'da sunulmuştur.

Tablo 6. Kontrol Grubunun Ön Test, Son Test ve Kalıcılık Testi Puanlarına İlişkin Tekrarlı Ölçümlerde ANOVA Sonuçları

\begin{tabular}{|c|c|c|c|c|c|c|}
\hline $\begin{array}{l}\text { Varyansın } \\
\text { Kaynağı }\end{array}$ & KT & SD & KO & $\mathbf{F}$ & $\mathbf{p}$ & $\begin{array}{c}\text { Anlamlı } \\
\text { Fark }\end{array}$ \\
\hline Deneklerarası & 585.719 & 18 & 32.540 & \multirow{4}{*}{43.80} & \multirow{4}{*}{.00} & \multirow{4}{*}{$1-2,1-3$} \\
\hline Ölçüm & 535.825 & 2 & 267.912 & & & \\
\hline Hata & 220.175 & 36 & 6.116 & & & \\
\hline Toplam & 1341.719 & 56 & & & & \\
\hline
\end{tabular}

Tablo 6 incelendiğinde, kontrol grubunda yer alan öğretmen adaylarının ön test, son test ve kalıcılık testi puanları arasında istatistiksel olarak anlamlı bir farkın olduğu görülmektedir $(\mathrm{p}<.05)$. Bu farkın hangi ölçümler arasından kaynaklandığını belirlemek için gerçekleştirilen Bonferroni testi sonucuna göre, ön test-son test puanları arasında son test lehine ve ön testkalıcılık testi puanları arasında kalıcılık testi lehine istatistiksel olarak anlamlı bir fark vardır. $\mathrm{Bu}$ sonuçlara göre geleneksel öğretim yaklaşımında öğrenilen bilginin kalıcı olduğu görülmektedir.

\section{Üçüncü Alt Probleme İlişkin Bulgular}

Araştırmanın üçüncü alt problemi "Deney ve kontrol gruplarındaki öğretmen adaylarının akademik başarı son test puanları arasında anlamlı bir fark var mıdır?” şeklindedir. Bu probleme yanıt verebilmek için geliştirilen akademik başarı testi hem deney hem de kontrol grubuna son test olarak uygulanmış ve uygulamalardan elde edilen veriler analiz edilerek karşılaştırılmıştır.

Tablo 7. Deney ve Kontrol Grubundaki Öğretmen Adaylarının Akademik Başarı Son Test Puanlarına İlişkin Bağımsız Gruplar t-Testi Sonuçları

\begin{tabular}{llllllll}
\hline Grup & N & $\bar{x}$ & Ss & Sd & t & p & Etki \\
\hline
\end{tabular}




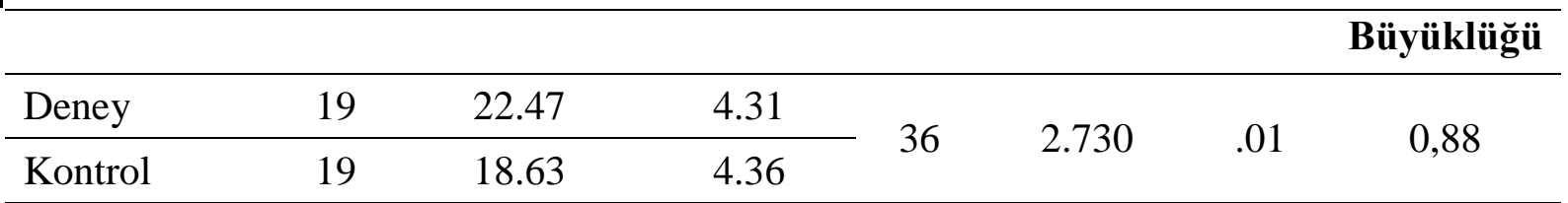

Tablo 7'de görüldüğü üzere, deney ve kontrol grubundaki öğretmen adaylarının akademik başarı son test puanları arasında istatistiksel olarak anlamlı bir farklılık vardır $(\mathrm{t}(36)=2.730 ; \mathrm{p}<.05)$. Deney ve kontrol grubunun son test puanlarının aritmetik ortalamas1 incelendiğinde, bu farklılı̆ğn deney grubu lehine olduğu görülmektedir. Bu bulgu, deney grubunda yapılan işlemin kontrol grubunda yapılan işleme göre daha etkili olduğunu göstermektedir.

Tablo 7'de ayrıca etki büyüklüğü değerlerine yer verilmiştir. Hesaplanan etki büyüklüğü 0,88 olarak bulunmuştur. Bu da etki büyüklüğünün “büyük” olduğunu göstermektedir.

\section{Dördüncü Alt Probleme İlişkin Bulgular}

Araştırmanın dördüncü alt problemi "Deney ve kontrol gruplarındaki öğretmen adaylarının akademik başarı kalıcılık testi puanları arasında anlamlı bir fark var mıdır?" şeklindedir. Bu probleme yanıt verebilmek için geliştirilen akademik başarı testi son test uygulamasından 4 hafta sonra hem deney hem de kontrol grubuna kalıcıllk testi olarak uygulanmış ve bu uygulamadan elde edilen veriler analiz edilerek gruplar karşılaştırılmıştır.

Tablo 8. Deney ve Kontrol Grubundaki Öğretmen Adaylarının Akademik Başarı Kalıcılık Testi Puanlarına İlişkin Betimsel İstatistikler

\begin{tabular}{llll}
\hline Grup & $\mathbf{N}$ & $\overline{\mathbf{x}}$ & Ss \\
\hline Deney & 19 & 20.95 & 3.91 \\
\hline Kontrol & 19 & 18.90 & 4.36 \\
\hline
\end{tabular}

Tablo 8 incelendiğinde, deney grubundaki öğretmen adaylarının kalıcılık testinden aldıkları puanların aritmetik ortalamasının $\overline{\mathrm{x}}=20.95$, kontrol grubundaki öğretmen adaylarının aritmetik ortalamasının ise $\overline{\mathrm{x}}=18.90$ olduğu görülmektedir. Bu bulgu, deney grubunda bulunan öğretmen adaylarının kalıcılık testi puanlarının kontrol grubundaki öğretmen adaylarının ortalamasından yüksek olduğunu göstermektedir.

Deney ve kontrol grubunda bulunan öğretmen adaylarının son test puanlarına göre düzeltilmiş akademik başarı kalıcılık testi puanlarının anlamlı farklılık gösterip göstermediğini belirlemek için gerçekleştirilen ANCOVA sonuçlarına Tablo 9' da yer verilmiştir.

Tablo 9. Deney ve Kontrol Grubunun Son Test Puanlarına Göre Düzeltilmiş Akademik Başarı Kalıcılık Testi Puanlarına Yönelik ANCOVA Sonuçları 


\begin{tabular}{llllll}
\hline Kaynak & KT & Sd & KO & F & P \\
\hline Son test & 419.117 & 1 & 419.117 & 74.23 & .00 \\
Grup & 7.406 & 1 & 7.406 & 1.31 & .26 \\
Hata & 197.620 & 35 & 5.646 & & \\
Toplam & 15737.000 & 38 & & & \\
\hline
\end{tabular}

Tabloda görüldüğü üzere, deney ve kontrol gruplarının son test puanlarına göre düzeltilmiş kalıcılık testi puanlarının istatistiksel olarak anlamlı bir farklılık göstermediği tespit edilmiştir $(\mathrm{F}(1,35)=1.529 ; \mathrm{p}>.05)$. Bu bulgu, EDOÖ modeli ile öğrenim gören öğretmen adayları ile mevcut uygulama ile öğrenim gören öğretmen adaylarının son test sonuçlarına göre düzenlenmiş kalıcılık testi puanlarının benzer olduğunu göstermektedir. Buna göre, EDOÖ modelinin öğrenmelerin kalıcılığına yeterli düzeyde etki etmediği söylenebilir.

\section{Beşinci Alt Probleme İlişkin Bulgular}

Araştırmanın beşinci alt problemi "Deney grubundaki öğretmen adaylarının son test, 1. kalıcılık ve 2. kalıcılık testi akademik başarı puanları arasında anlamlı bir fark var mıdır?" şeklindedir. Bu probleme yanıt verebilmek için geliştirilen akademik başarı testi deney grubuna son test, 1. kalıcılık ve 2. kalıcılık testi olarak uygulanmış ve uygulamalardan elde edilen veriler analiz edilmiştir.

Tablo 10. Deney Grubundaki Öğretmen Adaylarının Son Test, 1. Kalıcılık ve 2. Kalıcılık Testi Akademik Başarı Puanlarına İlişkin Betimsel İstatistikler

\begin{tabular}{llcc}
\hline Test & $\mathbf{N}$ & $\overline{\boldsymbol{x}}$ & Ss \\
\hline Son Test & 19 & 22.47 & 4.31 \\
\hline Kalıc1lk Testi 1 & 19 & 20.95 & 3.91 \\
\hline Kalıc1lk Testi 2 & 19 & 20.42 & 3.83 \\
\hline
\end{tabular}

Tablo 10 incelendiğinde, deney grubundaki öğretmen adaylarının son testten aldıkları puanların aritmetik ortalamasının $\bar{x}=22.47,1$. kalıcılık testinden aldıkları puanların aritmetik ortalamasının $\overline{\mathrm{X}}=20.95$ ve 2 . kalıcılık testinden elde ettikleri puanların aritmetik ortalamasının $\overline{\mathrm{x}}=20.42$ olduğu görülmektedir. Bu bulgu, deney grubunda bulunan öğretmen adaylarının son test puanlarının 1. kalıcılık ve 2. kalıcılık testi puanlarına göre daha yüksek olduğunu, 1 . kalıcılık ve 2. kalıcılık testi puanlarının ise birbirine oldukça yakın olduğunu göstermektedir.

Deney grubunda bulunan öğretmen adaylarının son test, 1. kalıcılık testi ve 2. kalıcılık testi puanları arasında anlamlı bir farklılık olup olmadığını belirlemek için yapılan Tekrarlı Ölçümlerde ANOVA Testi sonuçları Tablo 11'de verilmiştir. 
YYÜ Eğitim Fakültesi Dergisi (YYU Journal of Education Faculty), 2021;18(2)300-331,http://efdergi.yyu.edu.tr,

doi:10.33711/ yyuefd.1028611

ISSN: 1305-2020

Tablo 11. Deney Grubunun Son Test, 1. Kalıcılık ve 2. Kalıcılık Testi Puanlarına İlişkin Tekrarlı Ölçümlerde ANOVA Sonuçları

\begin{tabular}{|c|c|c|c|c|c|c|}
\hline $\begin{array}{l}\text { Varyansın } \\
\text { Kaynağı }\end{array}$ & KT & SD & KO & $\mathbf{F}$ & $\mathbf{p}$ & $\begin{array}{c}\text { Anlamlı } \\
\text { Fark }\end{array}$ \\
\hline Deneklerarası & 752.175 & 18 & 41.788 & \multirow{4}{*}{6.36} & \multirow{4}{*}{.00} & \multirow{4}{*}{$1-2,1-3$} \\
\hline Ölçüm & 43.193 & 2 & 21.596 & & & \\
\hline Hata & 122.141 & 36 & 3.393 & & & \\
\hline Toplam & 917.509 & 56 & & & & \\
\hline
\end{tabular}

Tablo 11'de görüldüğü üzere, deney grubunda bulunan öğretmen adaylarının son test, 1. kalıcılık ve 2. kalıcılık testi puanları arasında istatistiksel olarak anlamlı bir farklılık vardır $(\mathrm{p}<.05)$. Bu farkın hangi ölçümler arasından kaynaklandığını belirlemek amacıyla başvurulan Bonferroni testi sonucuna göre, son test-1. kalıcılık test puanları arasında son test lehine ve son test-2. kalıcılık testi puanları arasında yine son test lehine anlamlı bir fark vardır. Bu bulgulara göre, EDOÖ modelinde öğrenmelerin kalıcılığının düşük olduğu ve unutmanın daha hızlı olduğu söylenebilir.

\section{Altıncı Alt Probleme İlişkin Bulgular}

Araştırmanın altıncı alt problemi "Kontrol grubundaki öğretmen adaylarının son test, 1. kalıcılık ve 2. kalıcılık testi akademik başarı puanları arasında anlamlı bir fark var mıdır?" şeklindedir. Bu probleme yanıt verebilmek için geliştirilen akademik başarı testi kontrol grubuna son test, 1 . kalıcılık ve 2. kalıcılık testi olarak uygulanmış ve uygulamalardan elde edilen veriler analiz edilmiştir.

Tablo 12. Kontrol Grubundaki Öğretmen Adaylarının Son Test, 1. Kalıcılık ve 2. Kalıcılık Testi Akademik Başarı Puanlarına İlişkin Betimsel İstatistikler

\begin{tabular}{llcc}
\hline Test & $\mathbf{N}$ & $\overline{\boldsymbol{x}}$ & Ss \\
\hline Son Test & 19 & 18.63 & 4.36 \\
\hline Kalıc1lk Testi 1 & 19 & 18.90 & 4.36 \\
\hline Kalıc1lk Testi 2 & 19 & 19.58 & 2.50 \\
\hline
\end{tabular}

Tablo 12 incelendiğinde, kontrol grubundaki öğretmen adaylarının son testten aldıkları puanların aritmetik ortalamasının $\overline{\mathrm{x}}=18.63,1$. kalıcılık testinden aldıkları puanların aritmetik ortalamasının $\overline{\mathrm{x}}=18.90$ ve 2 . kalıcılık testinden elde ettikleri puanların aritmetik ortalamasının $\overline{\mathrm{x}}=19.58$ olduğu görülmektedir. Bu bulgular, kontrol grubunda bulunan öğretmen adaylarının son test, 1. kalıcılık ve 2. kalıcılık testi puanlarının birbirine oldukça yakın olduğunu, 2. kalıcılık 
YYÜ Eğitim Fakültesi Dergisi (YYU Journal of Education Faculty), 2021;18(2)300-331,http://efdergi.yyu.edu.tr,

testi puanlarının, son test ve 1. kalıcılık test puanlarına göre nispeten daha yüksek olduğunu göstermektedir.

Kontrol grubunda bulunan öğretmen adaylarının son test, 1. kalıcılık testi ve 2. kalıcılık testi puanları arasında anlamlı bir farklılık olup olmadığını belirlemek için yapılan Tekrarlı Ölçümlerde ANOVA Testi sonuçları Tablo 13'de verilmiştir.

Tablo 13. Kontrol Grubunun Son Test, 1. Kalıcılık ve 2. Kalıcılık Testi Puanlarına İlişkin Tekrarlı Ölçümlerde ANOVA Sonuçları

\begin{tabular}{|c|c|c|c|c|c|c|}
\hline $\begin{array}{c}\text { Varyansın } \\
\text { Kaynağı } \\
\end{array}$ & KT & SD & KO & $\mathbf{F}$ & $\mathbf{p}$ & $\begin{array}{c}\text { Anlamlı } \\
\text { Fark }\end{array}$ \\
\hline Deneklerarası & 603.263 & 18 & 33.515 & \multirow{4}{*}{.84} & \multirow{4}{*}{.44} & \multirow{4}{*}{---} \\
\hline Ölçüm & 9.088 & 2 & 4.544 & & & \\
\hline Hata & 193.579 & 36 & 5.377 & & & \\
\hline Toplam & 805.930 & 56 & & & & \\
\hline
\end{tabular}

Tablo 13 incelendiğinde, kontrol grubunda yer alan öğretmen adaylarının son test, 1.kalıcılık ve 2. kalıcılık testi puanları arasında istatistiksel olarak anlamlı bir fark olmadığ görülmektedir $(\mathrm{p}<.05)$. Bu bağlamda geleneksel yöntemlerle gerçekleşen öğrenmelerin daha kalıcı olduğu söylenebilir.

\section{Yedinci Alt Probleme İlişkin Bulgular}

Araştırmanın yedinci alt problemi "Deney ve kontrol gruplarındaki öğretmen adaylarının akademik başarı 2. kalıcılık testi puanları arasında anlamlı bir fark var mıdır?" şeklindedir. Bu probleme yanıt verebilmek için geliştirilen akademik başarı testi son test uygulamasından 6 ay sonra hem deney hem de kontrol grubuna 2. kalıcılık testi olarak uygulanmış ve bu uygulamadan elde edilen veriler analiz edilerek gruplar karşılaştırılmıştır.

Tablo 14. Deney ve Kontrol Grubundaki Öğretmen Adaylarının Akademik Başarı 2. Kalıcılık Testi Puanlarına İlişkin Bağımsız Gruplar t-Testi Sonuçları

\begin{tabular}{|c|c|c|c|c|c|c|}
\hline Grup & $\mathbf{N}$ & $\overline{\boldsymbol{x}}$ & Ss & Sd & $\mathbf{t}$ & $\mathbf{p}$ \\
\hline Deney & 19 & 20.42 & 3.82 & \multirow{2}{*}{36} & \multirow{2}{*}{.806} & \multirow{2}{*}{.42} \\
\hline Kontrol & 19 & 19.58 & 2.48 & & & \\
\hline
\end{tabular}

Tablo 14'de görüldüğü üzere, deney ve kontrol grubundaki öğretmen adaylarının akademik başarı 2. kalıcılık testi puanlarının istatistiksel olarak anlamlı bir farklılık göstermediği tespit edilmiştir $(\mathrm{t}(36)=.802 ; \mathrm{p}>.05)$. Bu bulguya göre, öğrenmelerin uzun vadede kalıcılığının sağlanmasında EDOÖ yöntemi ile geleneksel öğretim yöntemi arasında önemli bir farklılık olmadığı söylenebilir. 


\section{Nitel Verilere İlişkin Bulgular}

Araştırmanın bu bölümünde deney grubunda yer alan 19 öğretmen adayı ile yapılan görüşmelerden elde edilen bulgulara yer verilmiştir. Yapılan görüşmeler sonucunda ulaşılan bulgular şu kategoriler altında düzenlenmiştir: (a) Öğretmen adaylarının EDOÖ modelinin olumlu yönlerine ilişkin görüşleri, (b) Öğretmen adaylarının EDOÖ modelinin olumsuz yönlerine ilişkin görüşleri, (c) Öğretmen adaylarının EDOÖ modelinin daha etkili bir şekilde kullanımına yönelik önerileri.

\section{Öğretmen Adaylarının EDOÖ Modelinin Olumlu Yönlerine İlişkin Görüşleri}

Tablo 15. EDOÖ Modelinin Olumlu Yönleri/Avantajlarına İlişkin Görüşler

\begin{tabular}{lll}
\hline Tema & Kodlar & $\boldsymbol{f}$ \\
\hline & Etkili öğrenmenin sağlanması & 11 \\
& Aktif katılım & 10 \\
& Derse hazır gelme & 10 \\
EDÖ̈ modelinin olumlu & Öğrenmelerin kalıcılığı & 7 \\
yönlerine ilişkin öğretmen & Teknolojik olanakların sağladı̆̆ı esneklik & 5 \\
adayı görüşleri & Derse karşı ilgi/istek & 4 \\
& Sorumluluk kazanma & 4 \\
& Dersin eğlenceli/zevkli olması & 3 \\
& Özgüven kazandırma & 2 \\
\hline
\end{tabular}

Öğretmen adaylarına "Sizce EDOÖ modelinin geleneksel eğitime göre olumlu yönleri/avantajları nelerdir?” sorusu yöneltilmiştir. Görüşmelerde öğretmen adaylarının bu modele ilişkin birçok farklı olumlu özelliğe vurgu yaptıkları görülmüştür. Bu soruya ilişkin adayların sıklıkla atıfta bulundukları özellikler "Etkili öğrenmenin sağlanması" (n=11), "Aktif katılım” (n=10), “Derse hazır gelme” (n=10), “Öğrenmelerin kalıcılığı” (n=7), “Teknolojik olanakların sağladığ $(n=4)$, “Dersin eğlenceli/zevkli olması" $(n=3)$, “Özgüven kazandırma” $(n=2)$ olarak belirlenmiştir.

EDOÖ modelinin olumlu yönlerine ilişkin öğretmen adaylarının en çok vurgu yaptıkları durum, derslerin geleneksel eğitime nazaran daha etkili ve verimli geçtiğidir. Adaylar, EDOÖ modeli ile birlikte dersleri anlamanın daha kolay olduğunu belirtmişler ve özellikle sınıf içi süreçte işe koşulan etkinliklerin öğrenmeyi kolaylaştırdığına atıfta bulunmuşlardır. Öğretmen adaylarının bu konuya ilişkin genel bakışını yansıtan bazı örnek görüşlere aşağıda yer verilmiştir. 
“Öğrencilerin dersi anlaması noktasında çok iyi. En azından benim açımdan çok iyi geçti diyebilirim. Şöyle ki notları okuyorsun, videoları izliyorsun, derste de konu tekrar ediliyor yani öğrenci açısından bahane kalmamıştır, öğrenme için her şey yapılmıştır" (Ö15).

“...Diğer bir olumlu yön ise sınıfta gerçekleştirilen bu ödev/alıştırma gibi etkinlikler ile çok fikirliliğin sağlanması. Yani sınıf kalabalık olduğundan tartışılan örneklerde o kadar fazla oluyor ve bu durum bizim düşünce ufkumuzun daha çok genişlemesini sağlıyor” (Ö18).

“...Dersler etkileşimli ve uygulamalı işlendiği için öğrencinin konuyu özümsemesi daha kolay oluyor” (Ö1).

\section{Öğretmen Adaylarının EDOÖ Modelinin Olumsuz Yönlerine İlişkin Görüşleri}

Öğretmen adaylarına "Sizce EDOÖ modelinin geleneksel eğitime göre olumsuz yönleri/dezavantajları nelerdir?” sorusu yöneltilmiştir. Görüşme yapılan 19 öğretmen adayından 5'i bu modele ilişkin herhangi bir olumsuzluk yaşamadıklarını belirtmişlerdir. Modelin olumsuz yönlerine ilişkin olarak görüş bildiren öğretmen adayları birçok farklı duruma atıfta bulunmuşlardır. Öğretmen adaylarının EDOÖ modelinin olumsuz yönlerine ilişkin olarak sıklıkla vurgu yaptıkları durumların başında internete ulaşım ve buna bağlı olarak videoları izlemede yaşanan güçlükler gelmektedir.

"Bu uygulama video izlemeye dayalı olduğu için sıkıntı oluşturabiliyor. Çünkü her öğrencinin böyle bir imkânı olmayabiliyor. Bunun dışında bir dezavantajının olduğunu düşünmüyorum” (Ö11).

"Hoşuma gitmeyen bir şey yoktu sadece video izleme kısmında biraz sıkıntı yaşıyorduk o da yurtta kaldığımız için internet konusunda sıkıntı yaşıyorduk. Başka bu konuda bir sıkıntı yoktu. Dersi en güzel şekilde işlediğimizi düşünüyorum” (Ö17).

Öğretmen Adaylarının EDOÖ Modelinin Daha Etkili Bir Şekilde Kullanımına

\section{Yönelik Önerileri}

Öğretmen adaylarına EDOÖ modelinin daha etkili olarak yürütülebilmesine ilişkin sınıf içi süreç, sınıf dışı süreç ve teknolojik olanaklar ve materyaller bağlamında önerileri sorulmuştur. Öğretmen adaylarının büyük bir çoğunluğu bu soruyu yanıtsız bırakmış, modelin hâlihazırda en iyi şekilde uygulandığını ve herhangi bir eksiğinin bulunmadığını belirtmişlerdir. Adaylardan biri öğrencilerin modelin eksik buldukları yönlerini kendilerine en uygun şekilde farklı yollarla telafi edebileceklerini belirtmiş ve bu durumu da EDOÖ modelinin bir getirisi olarak nitelendirmiştir. Bazı adaylar ise Beyaz Pano gibi öğrenciler tarafından bilinmeyen bir 
uygulama yerine aynı işlevi görebilecek Facebook tarzı herkes tarafından bilinen ve kullanılan bir uygulamanın daha iyi sonuçlar verebileceğini, öğrencilerin bu uygulamayı daha rahat bir şekilde kullanacağını öne sürmüşlerdir.

\section{Sonuç, Tartışma ve Öneriler}

\section{Akademik Başarı ve Kalıcılık İle İlgili Sonuçlar ve Tartışma}

EDOÖ modelinin etkililiğini ortaya koyan en önemli değişkenin akademik başarı testi olduğu düşünülmektedir. Bu doğrultuda modelin işe koşulduğu deney grubunun ön test, son test ve kalıcılık testi puanları arasında anlamlı bir fark olup olmadığı incelenmiştir. Deney grubunda yer alan öğretmen adaylarının akademik başarı ön test-son test puanlarına bakıldığında son test lehine anlamlı bir farklılık olduğu ve öğrenmelerin önemli derecede arttığı görülmüştür. Uygulamanın sona ermesinden 4 hafta sonra yapılan kalıcılık testi ile ön test puanları arasında kalıcılık testi lehine, son test-kalıcılık testi arasında ise son test lehine anlamlı bir fark ortaya çıkmıştır. Bu sonuçlara göre EDOÖ modelinin akademik başarıya olumlu yönde bir etkisinin olduğu ifade edilebilir. Modelin öğrenmelerin kalıcılığına olan etkisinin ise öğrenmelerin gerçekleşmesine etkisine oranla daha sınırlı olduğu görülmüştür. Nitekim ortalamalara bakıldığında, öğretmen adaylarının ön testten aldıkları puanların aritmetik ortalamasının $\overline{\mathrm{x}}=12.21$, son testten aldıkları puanların aritmetik ortalamasının $\overline{\mathrm{x}}=22.47$ ve kalıcılık testinden elde ettikleri puanların aritmetik ortalamasının $\overline{\mathrm{x}}=20.95$ olduğu görülmektedir. Bu sonuçlar, kalıcılık testi puanlarının ön test puanlarına göre oldukça yüksek olduğunu, son test puanlarına göre ise kısmi bir azalma olduğunu ortaya koymaktadır. Buna göre, EDOÖ modeli uygulamalarının öğrenmelerin kalıcılığından çok akademik başarı üzerinde olumlu bir etkiye sahip olduğu anlaşılmaktadır.

Geleneksel öğretim yönteminin işe koşulduğu kontrol grubunda yer alan öğretmen adaylarının da ön test, son test ve kalıcılık testi puanları arasında anlamlı bir fark olup olmadığ incelenmiştir. Kontrol grubunda yer alan öğretmen adaylarının akademik başarı ön test-son test puanları arasında son test lehine ve ön test-kalıcılık testi puanları arasında kalıcılık testi lehine anlamlı bir fark bulunmuştur. Buna rağmen kontrol grubunun akademik başarı testleri ortalamalarına bakıldığında kontrol grubunda elde edilen başarının deney grubuna nazaran daha düşük olduğu görülmektedir. Nitekim kontrol grubunda yer alan öğretmen adaylarının ön testten aldıkları puanların aritmetik ortalaması $\overline{\mathrm{X}}=12.26$, son testten aldıkları puanların aritmetik ortalaması $\overline{\mathrm{X}}=18.63$ ve kalıcılık testinden elde ettikleri puanların aritmetik ortalamas $\overline{\mathrm{X}}=18.90$ olarak bulunmuştur. Buna göre kontrol grubunun son test ve kalıcılık testinden elde ettikleri puanların ortalamalarının deney grubuna göre 3-4 puan daha aşağıda olduğu görülmektedir. Bu 
durum deney grubunda işe koşulan EDOÖ modelinin geleneksel yönteme göre daha etkili sonuçlar meydana getirdiği şeklinde yorumlanabilir. Kontrol grubuna ait kalıcılık testinden elde edilen puanlar ön test ve son test ile karşılaştırıldığında, kontrol grubunun da deney grubuna paralel olarak kalıcılık bağlamında olumlu sonuçlar ortaya koyduğu anlaşılmaktadır.

Çalışmada EDOÖ modelinin işe koşulduğu deney grubu öğretmen adayları ile kontrol grubunda yer alan öğretmen adaylarının akademik başarı son test puanları karşılaştırıldığında deney grubu lehine istatistiksel olarak anlamlı bir fark olduğu görülmektedir. Buna göre deney grubunda yer alan öğretmen adayları kontrol grubundaki öğretmen adaylarına göre akademik başarı bağlamında daha yüksek puanlar almışlardır. Bu sonuç, öğrenmelerin sınıf dışı süreçte videolar ve ders notları aracılığıyla edinildiği dolayısıyla öğrencilere kendi öğrenme hızlarında ilerleme olanağı tanıyan, sınıf içi süreçte ise öğrenen merkezli aktiviteler ile öğrenmelerin pekiştirildiği EDOÖ modelinin akademik başarı bağlamında nitelikli sonuçlar ortaya koyduğunu göstermektedir. Literatürde EDOÖ modelinin akademik başarı üzerinde olumlu bir etkiye sahip olduğunu ortaya koyan birçok deneysel çalışma bulunmaktadır (AlsancakSırakaya, 2015; Boyraz, 2014; Çakır, 2017; Çukurbaşı ve Kıyıcı, 2017; Güven-Demir, 2018; Hwang ve Lai, 2017; Katsa, Sergis ve Sampson, 2016; Lim ve Wilson, 2018; Lo ve Hew, 2017; Marlowe, 2012; Nayci, 2017; Öztürk ve Alper, 2019; Özüdoğru, 2018; Pearson, 2012; Pierce ve Fox, 2012; Sağlam, 2016; Smith, 2018; Talley ve Scherer, 2013; Tully, 2014; Turan, 2015; Yıldız ve Kıyıc1, 2016).

Özkurkudis ve Bümen (2019) ve Qader (2017) yapmış oldukları farklı çalışmalarda birbirine benzer şekilde EDOÖ modelinin yabancı dil lisans öğrencilerinin yazma becerilerine etkisini incelemişlerdir. Her iki çalışmada da son testlerden elde edilen sonuçlar modelin uygulandığı deney grubu lehine anlamlı bir farklılık olduğunu göstermektedir. Bu sonuçlara göre EDOÖ modelinin işe koşulduğu sınıfta yer alan öğrenciler yazı yazma testlerinde kontrol grubu öğrencilerinden daha iyi bir performans sergilemişlerdir.

EDOÖ modeli ile elde edilen başarı, öğrencilerin, öğretmenleri ve sınıf arkadaşlarıyla daha fazla etkileşime girmesi (Turan, 2015), modelin öğrenenlere aktif bir öğrenme ortamı sunması (Alsancak-Sırakaya, 2015), sınıf içi sürecin öğrenen merkezli aktivitelerle daha verimli bir şekilde yürütülmesi (Katsa, Sergis ve Sampson, 2016), öğrencilere kendi hızlarında öğrenme olanağı sunması (Tully, 2014), derse hazır olarak gelmelerinden dolayı öğrencilere geleneksel sınıfa göre daha fazla konuşma ve derse katılma olanağı tanıması (Marlowe, 2012) gibi nedenlere bağlanabilir. 
EDOÖ modelinin akademik başarıya herhangi bir olumlu etkide bulunmadığını ortaya koyan çalışmalar da bulunmaktadır. Benzer şekilde deneysel desen ile yürütülmüş olan bu çalışmalarda, EDOÖ modelinin farklı değişkenlere yönelik olumlu etkileri bulunmuşsa da akademik başarı üzerinde olumlu bir etkisine rastlanmamıştır (Benjamin, 2019; Clark, 2015; Findlay-Thompson ve Mombourquette, 2014; Heredia, 2015; McLaughlin vd., 2013; Saunders, 2014; Zownorega, 2013).

Ayrıca öğrencilerin bireysel olarak çalışabilme, sorumluluk sahibi olma gibi bir takım becerilere sahip olması ve ders dışı süreçte yükümlülüklerini yerine getirmesi modelin başarılı bir şekilde yürütülebilmesi açısından büyük önem arz etmektedir (Clark, 2015). Nitekim sınıf içi sürecin nitelikli olarak yürütülebilmesi öğrencilerin sınıf dışı sürece ait sorumluluklarını yerine getirmeleri ile doğrudan ilişkilidir. Bu doğrultuda öğrencilerin yükümlülüklerini tam olarak yerine getirmediği bir uygulama sürecinden istendik sonuçlar elde edilemeyeceği öngörülmektedir.

Çalışmada deney ve kontrol grubu öğretmen adaylarına uygulanan akademik başarı testi, EDOÖ modelinin kalıcılık üzerindeki etkisini ölçmek üzere uygulama sona erdikten dört hafta sonra her iki gruba da tekrardan uygulanmıştır. Bu uygulama ile modelin öğrenmelerin kalıcılığı üzerinde anlamlı bir etkiye sahip olup olmadığının ortaya çıkarılması amaçlanmıştır. Yapılan istatistikler deney grubundaki öğrencilerin kalıcılık testinden aldıkları puanların aritmetik ortalamasının ( $\overline{\mathrm{x}}=20.95)$ kontrol grubuna $(\overline{\mathrm{x}}=18.90)$ göre daha yüksek olduğunu ortaya koymaktadır. Buna rağmen deney ve kontrol gruplarının son test puanlarına göre düzeltilmiş kalıcılık testi puanlarının istatistiksel olarak anlamlı bir farklılık göstermediği tespit edilmiştir. EDOÖ modelinin işe koşulduğu sınıfta yer alan öğretmen adaylarının derse hazırlanarak gelmiş olması, sınıf içi süreçte ise öğrendiklerini pekiştirmeye yönelik olarak yapılan öğrenen merkezli etkinliklere tabi tutulmaları kalıcılık testinde deney grubu lehine anlamlı bir fark ortaya çıkacağı beklentisine neden olsa da bu yönde bir sonuca ulaşılamamıştır.

Ortaya çıkan bu sonuç, deney ve kontrol gruplarında yer alan öğretmen adaylarının aynı testi üçüncü defa çözmesinden dolayı sorulara aşina olunması ile ilişkilendirilebilir. Nitekim kontrol grubunun son test $(\overline{\mathrm{x}}=18.63)$ ve kalıcılık testi $(\overline{\mathrm{x}}=18.90)$ ortalamalarına bakıldığında deney grubuna benzer olarak testler arasında düşük bir farklılık olduğu görülmektedir. Bunun yanında kontrol grubu öğretmen adaylarının kalıcılık testi puanlarının son test puanlarına göre az da olsa yükselmiş olması ortaya konan savı destekler niteliktedir.

Deney ve kontrol gruplarında yer alan öğretmen adayları uygulama sürecinin sonunda son teste tabi tutulmuş daha sonra dersin içeriğine yönelik olarak herhangi bir uygulama 
yapılmadan geçen dördüncü haftanın akabinde kalıcılık testine tabi tutulmuşlardır. Buna rağmen kontrol grubu öğretmen adaylarının kalıcılık testinden elde ettikleri puan ortalamasının son teste göre yükselmesi soruların öğretmen adayları tarafından unutulmadığını göstermeye yönelik kuvvetli bir ihtimal olarak değerlendirilebilir.

Literatürde EDOÖ modeline ilişkin olarak yapılan çalışmalarda, modelin öğrenmelerin kalıcılığına etkisinin incelendiği az sayıda çalışma bulunmaktadır. Bahsi geçen çalışmalarda son test ve kalıcılık testleri arasında geçen sürelerin farklılaşması çalışmalar arası karşılaştırma yapmayı güçleştirmektedir. Bu doğrultuda kalıcılık testine yer verilen çalışmalar genelleme yapılmadan, birbirinden bağımsız olarak incelenecektir.

Graham, Cohen, Reynolds ve Huang (2019) tıp fakültesi öğrencilerine yönelik olarak yapmış oldukları çalışmalarında, EDOÖ modelinin uygulama sürecinin sona ermesinden 6 ay sonra deney ve kontrol grubunda yer alan öğrencileri kalıcılık testine tabi tutmuş ve deney grubu lehine anlamlı bir fark elde etmişlerdir. Taglieri vd. (2017) üniversite öğrencileri ile gerçekleştirmiş oldukları çalışmada, uygulamanın sona ermesinden 17 ay sonra deney ve kontrol gruplarını kalıcılık testine tabi tutmuş ve EDOÖ modelinin öğrenmelerin kalıcılığına olumlu yönde bir etkisinin olmadığı sonucuna ulaşmışlardır. Boyraz (2014) EDOÖ modelinin İngilizce öğretiminde akademik başarı ve kalıcılığa etkisini incelediği çalışmasında, uygulama sürecinin sona ermesinden iki hafta sonra deney ve kontrol gruplarını kalıcılık testine tabi tutmuş ve deney grubu lehine anlamlı bir fark elde etmiştir. Alsancak-Sırakaya (2015) ise EDOÖ modeli ile klasik harmanlanmış öğrenmeyi karşılaştırdığı çalışmasında, uygulama süreci sona erdikten 5 hafta sonra her iki grubu da kalıcılık testine tabi tutmuş ve EDOÖ modelinin işe koşulduğu deney grubu lehine anlamlı bir farklılık olduğu sonucuna ulaşmıştır.

Çalışmada uygulama sürecinin sona ermesinden 6 sonra deney ve kontrol grubunda yer alan öğretmen adayları ikinci bir kalıcılık testine tabi tutulmuştur. İkinci kalıcılık testi ile amaçlanan EDOÖ modelinin uzun vadede öğrenmelerin kalıcılığına olan etkisini ortaya koymaktır. Bu doğrultuda öncelikli olarak modelin işe koşulduğu deney grubunun akademik başarı son test $(\overline{\mathrm{x}}=22.47), 1$. kalıcılık $(\overline{\mathrm{x}}=20.95)$ ve 2. kalıcılık testi $(\overline{\mathrm{x}}=20.42)$ puanları arasında anlamlı bir fark olup olmadığı incelenmiştir. Deney grubunda yer alan öğretmen adaylarının akademik başarı son test-1. kalıcılık test puanları arasında son test lehine ve son test-2. kalıcılık testi puanları arasında da son test lehine anlamlı bir farklılık olduğu görülmektedir.

Kontrol grubunda yer alan öğretmen adaylarının da akademik başarı son test $(\bar{x}=18.63)$, 1. kalıcılık ( $(\overline{\mathrm{x}}=18.90)$ ve 2 . kalıcılık testi $(\overline{\mathrm{x}}=19.58)$ puanları arasında anlamlı bir fark olup olmadığı incelenmiştir. Kontrol grubunda yer alan öğretmen adaylarının akademik başarı son 
test, 1.kalıcılık ve 2. kalıcılık testi puanları arasında istatistiksel olarak anlamlı bir farklılık olmadığı görülmektedir.

Çalışmada deney ve kontrol gruplarının ikinci kalıcılık testi puanlarının karşılaştırılması sonucunda istatistiksel olarak anlamlı bir farklılık göstermediği tespit edilmiştir. Yapılan istatistikler ikinci kalıcılık testinden alınan puanların birbirine oldukça yakın olduğunu ortaya koymaktadır. Deney grubunda yer alan öğretmen adaylarının ikinci kalıcılık testinden elde ettikleri puanların aritmetik ortalamasının $\overline{\mathrm{x}}=20.42$, kontrol grubu öğretmen adaylarının ise $\overline{\mathrm{X}}=19.58$ olduğu görülmektedir. Her ne kadar ikinci kalıcılık testi puanları arasında anlamlı bir farklılık çıkmamışsa da deney ve kontrol gruplarının ikinci kalıcılık test puanları, son testler ve birinci kalıcılık testlerinden elde edilen puanlar dikkate alınarak incelendiğinde kontrol grubunun uzun vadede öğrenmelerin kalıcılı̆̆ı noktasında bir adım önce olduğu söylenebilir. Nitekim deney grubunun son test, 1 . kalıcılık ve 2. kalıcılık test puanları arasında düzenli bir düşüş gözlenirken kontrol grubunda aksi yönde bir seyir gerçekleşmiştir.

İkinci kalıcılık testine ilişkin elde edilen sonuçlar, EDOÖ modelinin uzun vadede öğrenmelerin kalıcılığı noktasında olumlu bir etkiye sahip olmadığı şeklinde yorumlanabilir. Akademik başarı bağlamında modele ilişkin elde edilen başarının, öğrenmelerin uzun vadede kalıcılığı noktasında elde edilememesi üzerinde çalışılması gereken bir konu olarak değerlendirilmiştir. Bu durum 1. kalıcılık testinde olduğu gibi öğretmen adaylarının akademik başarı testine aşina olduğu ve soruları hatırladığı gerekçesiyle ilişkilendirilebilir. Nitekim ikinci kalıcılık testiyle birlikte öğretmen adayları aynı başarı testini dördüncü kez almış bulunmaktadırlar.

EDOÖ modeline ilişkin yürütülen çalışmalarda modelin birçok değişken üzerindeki etkisi incelenmiştir. Buna göre EDOÖ modelinin; öz-yeterlik (Hwang ve Lai, 2017), motivasyon (Bhagat, Chang ve Chang, 2016; Çukurbaşı ve Kıyıcı, 2017; Katsa, Sergis ve Sampson, 2016), stres seviyesi (Marlowe, 2012), zihinsel risk alma (Çakır, 2017), kendi kendine öğrenme düzeyi (Öztürk ve Alper, 2019), öz-yönetimli öğrenme hazırbulunuşluğu (Alsancak-Sırakaya, 2015; Ceylaner, 2016), üstbilişsel farkındalık (Yıldız ve Kıyıc1, 2016) üzerinde olumlu bir etkiye sahip olduğu anlaşılmaktadır. Öte yandan EDOÖ modelinin; teknolojik öz-yeterlik (Heredia, 2015), planlama becerisi (Güven-Demir, 2018), bilişsel yük (Turan, 2015), eleştirel düşünme becerisi (Hantla, 2014; Saunders, 2014), epistemolojik inanç (Yıldız ve Kıyıcı, 2016), öğrenme transferi (Aydın, 2016) gibi değişkenler üzerinde olumlu bir etkisinin bulunmadığı görülmektedir. 


\section{Öğrenci Görüşleri İle İlgili Sonuçlar ve Tartışma}

Çalışmanın nitel boyutunda öğretmen adaylarının EDOÖ modeline ilişkin görüşlerine başvurulmuştur. $\mathrm{Bu}$ doğrultuda uygulama süreci sona erdikten sonra deney grubunda yer alan 19 öğretmen adayının tamamıyla yarı-yapılandırılmış görüşmeler gerçekleştirilmiştir.

EDOÖ modeline ilişkin yapılan deneysel çalışmaların önemli bir çoğunluğunda öğrenci görüşlerine başvurulduğu görülmektedir. Çalışmalarda öğrencilerin genel olarak EDOÖ modeline ilişkin olumlu bir tutuma sahip oldukları gözlemlenmiştir. Bu çalışmada da öğretmen adaylarının EDOÖ modeli ile ilgili genel olarak olumlu bir kanıya sahip oldukları anlaşılmaktadır.

Yarı-yapılandırılmış görüşmeler aracılığıyla elde edilen bulgulara göre öğretmen adayları EDOÖ modelini; etkili bir öğrenme sağlayan, aktif katılımı arttıran, derse karşı istek uyandıran, sorumluluk ve özgüven kazandıran bir model olarak ifade etmektedirler.

Deney grubu öğretmen adayları EDOÖ modelinin olumlu yönlerine ilişkin çeşitli görüşler ortaya koymuşlardır. Adaylarının yoğun olarak belirttikleri durumların başında, modelin geleneksel eğitime göre daha etkili ve verimli bir öğrenme ortamı sağladığ1 gelmektedir. Öğretmen adayları özellikle sınıf içi süreçte işe koşulan öğrenci merkezli etkinliklerin öğrenmeyi kolaylaştırdığına atıfta bulunmuşlardır. Adaylar ayrıca ders dışı ve ders içi süreçlerin birbirini tamamladığını, ders dışı süreçte videolar ve ders notları aracılığıyla öğrendiklerinin ders içi süreçte pekiştirildiğini belirtmişlerdir. Boyraz (2014) da benzer avantajlardan bahsetmektedir. Yapmış olduğu çalışmada deney grubu öğrencilerin modelin daha iyi öğrenmelerine katkı sağladıklarını belirttiklerini vurgulamaktadır. Benjamin (2019) EDOÖ modelinin öğrenciler tarafindan oldukça benimsendiğini ifade etmekte ve bunun en temel nedeni olarak modelin öğrencilerin beklentilerine de cevap verecek şekilde etkili öğrenmeyi sağladığını belirtmektedir. Alsancak-Sırakaya (2015) da benzer olarak EDOÖ modelinin öğrenciler tarafından eğitsel açıdan etkili bir model olarak nitelendirildiğini ortaya koymaktadir.

Öğretmen adaylarının EDOÖ modelinin olumlu yönlerine ilişkin sıklıkla vurguladıkları bir diğer durum modelin öğrenenlere derse aktif katılım olanağı sağlamasıdır. Videolar ve ders notları aracılığıyla derse hazırlanarak gelen öğretmen adayları, işlenecek konuya hâkim olmanın sağladığı avantajla öğrenme süreçlerinde aktif bir rol üstlenmişlerdir. Bu durum öğretmen adayları ile yapılan görüşmelerden elde edilen bulgularda da yoğun olarak 
görülmektedir. Adaylar genel olarak EDOÖ modelinin aktif katılımı desteklediğini ve kolaylaştırdığını belirtmekte, bazı öğretmen adayları ise normalde hiç yapmadıkları ve kendilerinden beklemedikleri bir şekilde derslere aktif katılım sağladıklarını ifade etmektedirler. Findlay-Thompson ve Mombourquette (2014) EDOÖ modeline ilişskin öğrenci görüşlerinden elde ettikleri bulgulara göre, öğrencilerin bu modelde derse daha çok katılım sağladıklarını, öğretmene ve sınıf arkadaşlarına rahat bir şekilde soru sorabildiklerini, bunun da daha etkili bir öğrenme sürecine yol açtığını belirtmektedirler. Marlowe (2012) EDOÖ modelinin düşük başarı seviyesine sahip olan öğrencilerde meydana getirdiği olumlu gelişmenin nedenini, EDOÖ modeli ile birlikte öğrencilerin derse aktif katılım sağlamasına ve geleneksel öğretim modeline göre öğretmenle daha çok iletişime geçme imkânına sahip olmalarına bağlamaktadır. Clark (2015) tarafından yürütülen çalışmada odak grup görüşmelerinden elde edilen bulgulara göre öğrenciler aktif katılımı, modelin akademik başarı üzerindeki olumlu etkisinin en temel belirleyicisi olarak değerlendirmektedirler.

Çalışmanın nicel boyutundan elde edilen bulgulara göre EDOÖ modelinin öğrenmelerin kalıcılığına olumlu bir etkide bulunmadığı görülse de, görüşüne başvurulan öğretmen adaylarının birçoğu modelin kalıcılık üzerinde olumlu bir etkiye sahip olduğunu düşünmektedirler. Literatürde EDOÖ modelinin öğrenmelerin kalıcılığına etkisinin incelendiği az sayıda çalışma bulunsa da, yapılan görüşmelerde öğrencilerin bu konuya sıklıkla atıfta bulundukları görülmektedir. Alsancak-Sırakaya (2015) tarafından yürütülen çalışmada görüşlerine başvurulan öğrenciler EDOÖ modelinin derse evde hazırlanma, ders esnasında tartışma ve istedikleri zaman materyallere ulaşarak tekrar etme imkânına sahip olma gibi nedenlerden dolayı kalıcılık üzerinde olumlu bir etkiye sahip olduğunu ifade etmektedirler. Urfa (2017) tarafından yürütülen çalışmada öğrencilerden elde edilen görüşlere göre kalıcılık ve aktif katılım EDOÖ modelinin geleneksel yönteme göre en güçlü iki yönü olarak değerlendirilmektedir. Yavuz (2016) tarafından yürütülen çalışmada ise öğrenciler öğrenmelerin kalıcılığının sağlanmasını modele ilişkin üst düzey bir kazanım olarak nitelendirmektedirler. Öğrenciler modelin; evde video izleme olanağı sunması, anlaşılmayan yerlerin derste öğretmene sorulabilmesi, evde internetten konu ile ilgili araştırma yapılabilmesi ve sınıf içi süreçte yapılan öğrenen merkezli aktivitelerden dolayı kalıcılık üzerinde olumlu bir etkiye sahip olduğunu ifade etmektedirler.

Çalışmada EDOÖ modelinin işe koşulduğu grupta yer alan öğretmen adaylarının modele ilişkin bir takım olumsuzluklardan da bahsettikleri görülmektedir. Öğretmen adayları internete ulaşmanın her zaman için çok kolay olmadığına ve buna bağlı olarak videoları 
izlemede yaşadıkları güçlüklere değinmektedirler. Bunun yanında videoları izlerken anlamadıkları yerlerde soru sorma olanağına sahip olmamaları öğretmen adayları tarafından olumsuz bir durum olarak ifade edilmektedir. Bazı adaylar ise her hafta video izlemek ve ders notlarını çalışmak zorunda olmalarının bir süre sonra yoruculuğa ve bıkkınlığa sebep olduğunu ifade etmektedirler.

Sonuç olarak EDOÖ modelinin öğretmen adaylarının akademik başarıları üzerinde önemli derecede olumlu etki sağladığı, öğrencilerin öğrenmelerini kolaylaştırdığı görülmüş olmasına rağmen öğrenmelerin kalıcılığı noktasında aynı derecede etkili olmadığı anlaşılmaktadır. Bu durum öğrenmelerin gerçekleştirilmesinde EDOÖ modelinin yaygın olarak kullanılabileceğini, öğrenmelerin kalıcılığının sağlanması için ise ek etkinliklere ihtiyaç olduğunu göstermektedir.

\section{Öneriler}

$\mathrm{Bu}$ bölümde araştırmadan elde edilen bulgulardan hareketle EDOÖ modeli uygulamalarının geliştirilmesine ve yeni yapılacak araştırmalara ilişkin geliştirilen önerilere yer verilmiştir.

- $\quad$ Öğrencilerin modele ilişkin eleştirileri genel olarak sınıf dışı süreç üzerinde yoğunlaşmaktadır. Bu doğrultuda ders dişı süreçte öğrencilerin faydalanacağ videolar, materyaller ve online platformun itina ile, öğrencilerin beklentilerine cevap verecek şekilde belirlenmesi önerilebilir.

- $\quad$ EDOÖ modelinin başat öğretim modeli olarak seçilmesi dersin tamamının bu model ile yürütülmesi gerektiği anlamını taşımamaktadır. Buna göre geleneksel sunuş yönteminin dersin içeriği açısından daha uygun görüldüğü haftalarda bu yönteme başvurulabilir. Böylelikle öğrencilerin modelin olumsuz yönlerinden biri olarak değerlendirdikleri her hafta video izlemenin sıkıcılığa yol açtığ gerekçesinin önüne geçilebilir.

- $\quad$ EDOÖ modelinin akademik başarı üzerindeki etkisinin ölçüleceği çalışmalarda akademik başarı testinin yanı sıra süreç sonunda sözlü imtihanlar yapılarak daha etkili sonuçlar elde edilebilir.

\section{Makalenin Bilimdeki Konumu}

Eğitim Bilimleri Alanı/Eğitim Programları ve Öğretim Bilim Dalı

\section{Makalenin Bilimdeki Özgünlüğü}

Çalışma öğretmen adayları üzerinde akademik başarı, öğrenmelerin kalıcılığı ve sınıf iklimi değişkenlerini çağdaş bir öğrenme yaklaşımı olan EDOÖ modeli ile ele almaktadır. Bu 
bağlamda Eğitim Fakültelerinde görev alan öğretim elemanlarına alternatif bir eğitim süreci sunmaktadır. Ayrıca bu model geleceğin öğretmenleri için de mesleki yaşantılarında işe koşabilecekleri bir öğrenme yaklaşımı olarak düşünülebilir.

\section{Kaynakça}

Adıgüzel, A. (2016). Öğretim ilke ve yöntemleri: Süreçler stratejiler yaklaşımlar ve modeller, Ankara: Vize Yayıncılık.

Akınoğlu, O. (2005). Türkiye'de uygulanan ve değişen eğitim programlarının psikolojik temelleri. M.Ü. Atatürk Eğitim Fakültesi Eğitim Bilimleri Dergisi, 22, 31-46.

Alsancak-Sırakaya, D. (2015). Ters yüz sınıf modelinin akademik başarı, öz-yönetimli öğrenme hazırbulunuşluğu ve motivasyon üzerine etkisi. Yayınlanmamış Doktora Tezi. Gazi Üniversitesi Eğitim Bilimleri Enstitüsü, Ankara.

Aydın, B. (2016). Ters yüz sınıf modelinin akademik başarı, ödev/görev stres düzeyi ve öğrenme transferi üzerindeki etkisi. Yayınlanmamış Yüksek Lisans Tezi. Süleyman Demirel Üniversitesi Eğitim Bilimleri Enstitüsü, Isparta.

Baker, J. W. (2000). The 'Classroom Flip’: Using web course management tools to become the guide by the side. Jack A. Chambers (Ed.), Selected Papers from the 11th International Conference on College Teaching and Learning içinde, (s. 9-17). Jacksonville, FL: Florida Community College at Jacksonville.

Balc1, A. (2011). Sosyal bilimlerde araştırma: Yöntem, teknik ve ilkeler. Ankara: Pegem A Yayıncilik.

Benjamin, C. M. (2019). Effects of flipped lessons on academic performance and student involvement in an anatomy and physiology course. Doctoral dissertation, Delta State University, Cleveland.

Bergmann, J. and Sams, A. (2008) Remixing chemistry class. Learning and Leading with Technology, 36(4), 24-27.

Bergmann, J. and Sams, A. (2012). Flip your classroom: Reach every student in everyclass everyday. Washington, DC: Internal Society for Technology in Education.

Bhagat, K. K., Chang, C. N. and Chang, C. Y. (2016). The impact of the flipped classroom on mathematics concept learning in high school. Journal of Educational Technology \& Society, 19(3), 134-142.

Boyraz, S. (2014). İngilizce öğretiminde tersine eğitim uygulamasının değerlendirilmesi. Yayınlanmamış Yüksek Lisans Tezi. Afyon Kocatepe Üniversitesi Sosyal Bilimler Enstitüsü, Afyon. 
Büyüköztürk, Ş., Kılıç-Çakmak, E., Akgün, Ö. E., Karadeniz, Ş., ve Demirel, F. (2012). Bilimsel araştırma yöntemleri. Ankara: Pegem A Yayıncılık.

Ceylaner, S. (2016). Dokuzuncu sınıf ingilizce öğretiminde ters yüz sınıf yönteminin öğrencilerin öz yönetimli öğrenmeye hazırbulunuşluklarına ve ingilizce dersine yönelik tutumlarına etkisi. Yayınlanmamış Yüksek Lisans Tezi. Mersin Üniversitesi Eğitim Bilimleri Enstitüsü, Mersin.

Clark, K. R. (2015). The effects of the flipped model of instruction on student engagement and performance in the secondary mathematics classroom. Journal of Educators Online, 12(1), 91-115.

Creswell, J. W. (2013). Research design. Qualitative, quantitative, and mixed methods approaches. USA: Sage publications Inc.

Çakır, E. (2017). Ters yüz sınıf uygulamalarının fen bilimleri 7. sınıf öğrencilerinin akademik başarı, zihinsel risk alma ve bilgisayarca düşünme becerileri üzerine etkisi. Yayınlanmamış Yüksek Lisans Tezi, Ondokuz Mayıs Üniversitesi, Samsun.

Çukurbaşı, B. ve Kıyıcı, M. (2017). An investigation of the effects of problem-based learning activities supported via flipped classroom and LEGO-LOGO practices on the success and motivation of high school students. International Online Journal of Educational Sciences, 9(1), 1-16.

Findlay-Thompson, S. and Mombourquette, P. (2014). Evaluation of a flipped classroom in an undergraduate business course. Business Education \& Accreditation, 6(1), 63-71.

Fraenkel, J. R., Wallen, N. E. and Hyun, H. H. (2012). How to design and evaluate research in education. USA: The McGraw-Hill Companies, Inc.

Graham, K. L., Cohen, A., Reynolds, E. E. and Huang, G. C. (2019). Effect of a flipped classroom on knowledge acquisition and retention in an internal medicine residency program. Journal of graduate medical education, 11(1), 92-97.

Güven-Demir, E. (2018). Ters yüz sınıf modeline dayalı uygulamaların ilkokul 4. sınıf öğrencilerinin akademik başarı ve planlama becerilerine etkisi. Yayınlanmamış Doktora Tezi, Ondokuz Mayıs Üniversitesi Eğitim Bilimleri Enstitüsü, Samsun.

Hantla, B. F. (2014). The effects of flipping the classroom on specific aspects of critical thinking in a christian college: A quasi-experimental, mixed-methods study. Doctoral dissertation, Southeastern Baptist Theological Seminary, Wake Forest. 
Heredia, K. (2015). The effects of the flipped classroom model on student academic growth in flipped and traditional community college classrooms. Doctoral dissertation, Aurora University, College of Education, Aurora.

Herreid, C. F. and Schiller, N. A. (2013). Case studies and the flipped classroom. Journal of College Science Teaching, 42(5), 62-66.

Hwang, G. J. and Lai, C. L. (2017). Facilitating and bridging out-of-class and in-class learning: An interactive e-book-based flipped learning approach for math courses. Journal of Educational Technology \& Society, 20(1), 184-197.

Kaptan, S. (1998). Bilimsel araştırma ve istatistik teknikleri. Ankara: Tekışık Web Ofset.

Kardaş, F. ve Yeşilyaprak, B. (2015). Eğitim ve öğretimde güncel bir yaklaşım: teknoloji destekli esnek öğrenme (flippedlearning) modeli. Ankara Üniversitesi Eğitim Bilimleri Fakültesi Dergisi, 48(2), 103-121.

Katsa, M., Sergis, S. and Sampson, D. G. (2016). Investigating the potential of the flipped classroom mode in K-12 mathematics teaching and learning. In 13th International 84 conference on cognition and exploratory learning in digital age (pp. 210-218).

Lage, M.J., Platt, G. J. and Treglia, M. (2000). Inverting the classroom: A gate way to creating an inclusive learning environment. The Journal of Economic Education, 31(1), 30-43.

Leicht, R., Zappe, S., Litzinger, T. and Messner, J. (2012). Employing the classroom flip to move "lecture" out of the classroom. Journal of Applications and Practices in Engineering Education, 3(1), 19-31.

Lim, K. H. and Wilson, A. D. (2018). Flipped learning: Embedding questions in videos.

Mathematics Teaching in the Middle School, 23(7), 378-385.

Lo, C. and Hew, K. (2017). Using "first principles of instruction" to design secondary school mathematics flipped classroom: The findings of two exploratory studies. Journal of

Educational Technology \& Society, 20(1), 222-236.

Marlowe, C. A. (2012). The effect of the flipped classroom on student achievement and stres. Master's thesis, Montana State University, Bozeman.

McLaughlin, J. E., Griffin, L. M., Esserman, D. A., Davidson, C. A., Glatt, D. M., Roth, M. T., ... and Mumper, R. J. (2013). Pharmacy student engagement, performance, and perception in a flipped satellite classroom. American journal of pharmaceutical education, 77(9), 1-8. 
Nayci, Ö. (2017). Sosyal bilgiler öğretiminde ters yüz sınıf modeli uygulamasının değerlendirilmesi. Yayınlanmamış Doktora Tezi, Ankara Üniversitesi Eğitim Bilimleri Enstitüsü, Ankara.

Newman, G., Kim, J.H., Lee, R. J., Brown, B, A. and Huston, S. (2016). The perceived effects of flipped teaching on knowledge acquisition. The Journal of Effective Teaching, 16(1), 52-71.

Özkurkudis, M. J. and Bümen, N. T. (2019). Flipping the writing classroom: Using grammar videos to enhance writing. Journal of Education and Future, (15), 1-16.

Öztürk, S. ve Alper, A. (2019). Programlama öğretimindeki ters-yüz öğretim yönteminin öğrencilerin başarılarına, bilgisayara yönelik tutumuna ve kendi kendine öğrenme düzeylerine etkisi. Bilim, Eğitim, Sanat ve Teknoloji Dergisi, 3(1), 13-26.

Özüdoğru, M. (2018). Ters yüz öğrenmenin öğretmen adaylarının başarıları ve sınıf ortamı algılarına etkisi. Yayınlanmamış Doktora Tezi, Orta Doğu Teknik Üniversitesi Sosyal Bilimleri Enstitüsü, Ankara.

Pearson, G. (2012). Studnets, parents give thumbs-up to flipped classroom. Education Canada, 52(5), 46.

Pierce, R. and Fox, J. (2012). Vodcasts and active-learning exercises in a "flipped classroom" model of a renal pharmacotherapy module. American Journal of Pharmaceutical Education, 76(10), 1-5.

Qader, R. (2017). Dönüştürülmüşs sınıf eğitiminin İngilizce öğrenimi gören Iraklı öğrencilerin yazma becerileri üzerindeki etkileri. Yayınlanmamış Yüksek Lisans Tezi, Gaziantep Üniversitesi Eğitim Bilimleri Enstitüsü, Gaziantep.

Sağlam, D. (2016). Ters-yüz sınıf modelinin İngilizce dersinde öğrencilerin akademik başarılarına ve tutumlarına etkisi. Yayınlanmamış Yüksek Lisans Tezi. Bülent Ecevit Üniversitesi Sosyal Bilimler Enstitüsü, Zonguldak.

Saunders, J. (2014). The flipped classroom: Its effect on student academic achievement and critical thinking skills in high school mathematics. Doctoral Dissertation, Liberty University, Lynchburg.

Seaman, G. and Gaines, N. (2013). Leveraging digital learning systems to flipclassroom instruction. Journel of Modern Teacher Quarterly, 1, 25-27.

Smith, T. (2018). Active learning in the math classroom. Tech \& Learning, 38(7), 26-28.

Taglieri, C., Schnee, D., Camiel, L. D., Zaiken, K., Mistry, A., Nigro, S., ... and Goldman, J. (2017). Comparison of long-term knowledge retention in lecture-based versus flipped 
YYÜ Eğitim Fakültesi Dergisi (YYU Journal of Education Faculty), 2021;18(2)300-331,http://efdergi.yyu.edu.tr,

team-based learning course delivery. Currents in Pharmacy Teaching and Learning, 9(3), 391-397.

Talley, C. P. and Scherer, S. (2013). The enhanced flipped classroom: Increasing academic performance with student-recorded lectures and practice testing in a" flipped" STEM course. The Journal of Negro Education, 82(3), 339-347.

Tully, D. R. (2014). The effects of a flipped learning model utilizing varied technology verses the traditional learning model in a high school biology classroom. Master's thesis, Montana State University, Bozeman.

Turan, Z. (2015). Ters yüz sınıf yönteminin değerlendirilmesi ve akademik başarı, bilişsel yük ve motivasyona etkisinin incelenmesi. Yayınlanmamış Doktora Tezi. Atatürk Üniversitesi Eğitim Bilimleri Enstitüsü, Erzurum.

Urfa, M. (2017). Bilim etiği öğretiminde ters yüz sınıf modelinin uygulanması. Yayınlanmamış Yüksek Lisans Tezi, Balıkesir Üniversitesi Fen Bilimleri Enstitüsü, Balıkesir.

Yıldız, D. G. ve Kıyıcı, G. (2016). Ters yüz edilmiş sınıf modelinin öğretmen adaylarının erişilerine, üstbiliş farkındalıklarına ve epistemolojik inançlarına etkisi. Celal Bayar Üniversitesi Sosyal Bilimler Dergisi, 14(3), 423-444.

Zownorega, S. J. (2013). Effectiveness of flipping the classroom in a honors level, mechanic based physics class. Master's thesis, Eastern Illnois University, Graduate School, Charleston.

\section{Summary}

\section{Problem Statement}

Traditional teaching models are frequently criticized and lose value day by day due to reasons such as making learners inactive during the learning-teaching processes and failing to ensure for the retention of the knowledge. Therefore new approaches have begun to be adopted and implemented in order to have the students more active. Flipped Learning is one of the models that emerged as a result of the changes in teacher and student roles. Bergmann and Sams (2012), who pioneered the introducing of the model to the world, define the Flipped Learning model as a new method in which classroom and extra-class experiences are completely reversed, in which students learn the relevant subject before the lesson and attend the course prepared. In the course process of the Flipped Learning model, it is aimed that the students 
YYÜ Eğitim Fakültesi Dergisi (YYU Journal of Education Faculty), 2021;18(2)300-331,http://efdergi.yyu.edu.tr,

absorb the knowledge they have acquired before the course by making use of the benefits of the classroom environment.

\section{Method}

The aim of this study is to investigate the effect of flipped learning model on academic achievement, knowledge retention and long-term knowledge retention of prospective teachers and to determine their opinions concerning the model. In this study, mixed method design was used. The study was conducted in an "Educational Psychology" course with 38 prospective teachers who study Science Education in Faculty of Education in a public university. Prospective teachers were divided into two groups and the groups were randomly assigned as experimental and control groups. Flipped learning model was applied in the experimental group and for the control group traditional method was used. Quantitative and qualitative data collection tools were used in the study. Academic achievement test was used as a quantitative data collection tool and for the qualitative data collection, semi-structured interview form was used. Descriptive statistics, t-test for dependent and independent groups, ANOVA and ANCOVA tests were used for the analysis of quantitative data. For the analysis of qualitative data, descriptive and content analysis techniques were used.

\section{Findings and Discussions}

It was found that the academic achievement of the experimental group was significantly higher than the control group. Besides, it was found that there was no significant difference between knowledge retention of the prospective teachers in experimental and control groups. Six months after the application process there was no significant difference between experimental and control groups in terms of the second knowledge retention test results to measure the long-term knowledge retention. It was concluded that prospective teachers have a positive attitude towards the flipped learning model and considered the model as functional. According to the findings obtained from the qualitative data, prospective teachers consider it as an important advantage to attend the course prepared by studying the subject of the lesson at home through video or any other materials. Prospective teachers argue that attending to the lesson with preparation has an important effect on the retention of learning, active participation and the conduct of the lesson in a more efficient and fun way. According to the opinions of the prospective teachers, another advantage of the Flipped Learning model is that videos could be watched outside of the classroom therefore students have an opportunity to study their lessons whenever and wherever they want to. 
YYÜ Eğitim Fakültesi Dergisi (YYU Journal of Education Faculty), 2021;18(2)300-331,http://efdergi.yyu.edu.tr,

\section{Conclusions and Recommendations}

Although it has been seen that the Flipped Learning model has a significant positive effect on the academic achievement of prospective teachers and facilitates the learning process, it is understood that the model is not as effective in terms of the retention of knowledge. According to the results obtained from the study, prospective teachers' criticisms of the model generally focus on the out-of-classroom activities. Hereby it can be suggested that the videos, materials and online platforms that students will benefit from in the extracurricular process should be carefully determined to meet the expectations of the students. In addition, it can be suggested that in-class activities should be organized in a way that covers all students and gives equal opportunity to speak and participate as much as possible. 